\title{
Design of Smart Fuel Station and Management System Based on Arduino and Internet of Things
}

\author{
Budi Prijo Sembodo \\ Department of Electrical Engineering \\ University of PGRI Adi Buana Surabaya \\ budi@unipasby.ac.id
}

\author{
Haris Atmajaya \\ Department of Electrical Engineering \\ University of PGRI Adi Buana Surabaya \\ atm_haris@yahoo.co.id
}

\begin{abstract}
Patrol that is distributed to the public must meet the requirement for the quality, quantity and continuity. Pertamina as one of the companies that is responsible for the distribution of patrol to the public through gas stations and must have competent management and services. However, problems arise in the community and even companies in controlling fuel consumption and queues for sales services at gas stations. One solution is to use a station that is connected to smartphone wirelessly and a cashless.
\end{abstract}

Through the "Smart Fuel Station and Management System Based on Arduino and Internet Of Things", that will be able to help the community and companies in controlling their fuel consumtion and making savings. This monitoring tool uses the Arduino ESP8266 which is combined with Internet of Things (IoT) Technology which is displayed on the LCD and the Internet Web. Customers can purchase the patrol at gas stations independently, by connecting the smartphone application with the gas station wireless and purchase and make payments through the application. By having top up the balance on the application to be able to make purchases as needed and the balance will continue to decrease according to usage. The fuel filling station will issue it according to the nominal or the number of liters we choose in the application. Customers can view detailed fuel purchase for place, date, time, amount and total balance.

Keywords-Consumption Monitoring, Arduino, Internet of Things, E-money, ESP8266.
Fuel is one of the vital needs for living things on earth. Fuel is used by humans for various purposes, including fuel for motorized transportation, industry and energy sources. The population growth which is increasingly rapid has made the need for vehicle fuel continues to increase [1]. Gas Station is a public infrastructure provided by PT. Pertamina for distributing fuel needs which sould meet the requirement [2].

Based on previous studies using the RFID system [3], there are still some weaknesses which is still using officers for filling and payment transactions, so that there are still queues prchasing, especially during rush hours. In addition, it is common to find several stations that have unavailble officers, so they cannot be used optimally. Another drawback is that there are frequent frauds committed by drivers to get benefits in managing vehicle fuel needs due to the absence of a good management system in terms of automatic, online and integrated, and accurate historical.

Observing in this research, it is necessary to have a transaction system that allows consumers to be able to refuel independently (self-service) and cashless transactions and historical data can be stored into the data base for management system. Fuel consumption monitoring by the community or a company as in other research on monitoring water consumption [4], by using a flow meter sensor Yfs201 [5] as a sensor for the total volume of distributed fluid [6]. In order to be realized, it is necessary to create a tool that is able to carry out transactions independently and the data which can be applied to the purchase of fuel at gas stations.

In this study, an automatic fuel station will be designed and a fuel purchase management system as a part of online purchase data using

\section{INTRODUCTION}


Arduino [7] and the concept of the Internet of Things (IoT) [8] so that, when making transactions, customers simply enter the gas station, run the application. via a Smartphone to control the filling machine. Customers must have sufficient balance in the application to be able to make purchases. By topping up electronic money [9],[10], customers can add to their balance. This balance will decrease according to usage. There is a database to store every transaction in detail that can be seen online through application or internet.

\section{METHODS}

\subsection{Data Collection Methods}

Collection data is retrieving data from hardware and software to determine whether the system meet the expectation. The methods used in collecting the data include:

1. Observation, which observing while testing the haequipment has been made and measurements for further data analysis. This test includes:

- Testing (Flow meter, LCD, Keypad, IoT, Relay and Solenoid valve).

- Ttransactions simulation that is stored in the data base as a management system.

- Testing the control system on the application and filling balances.

2. Collect documentation of the results which are used as references to provide supporting knowledge.

\subsection{Data Analysis Methods}

The data analysis method used in this study used descriptive analysis, which is to describe the data according to the test results as follows:

1. A management system for monitoring fuel consumption displayed in a data base that can be accessed via an application on a Smartphone and an internet web browser

2. Fuel transactions using the Yf-S201 flow sensor which can be seen through displays, applications on Smartphone or the internet web controlled by Arduino.

3. Control system for pump station machines with Smartphone and top up ballance.

\section{RESULTS AND DISCUSSION}

\subsection{System Testing Results}

System testing is the process of executing system hardware and software to determine whether the system achieve the expectation. Which is done by conducting experiments to see possible errors that occur from each process.

\section{Communication System Testing}

Testing the communication system in the application consists of several types, namely communication between Arduino and devices, communication between Arduino and the Internet web to determine the communication process between the communication support system in the smart fuel station application so that conclusions can be drawn.

The communication interface with the web server is displayed on an LCD to make it easier for users to become more familiar with the equipment as follows.

a. Connect with registered Wifi

In this tool system, a wifi network is needed as an interface between the device and the web server. Figure 3.1 is the connectivity process with wifi.

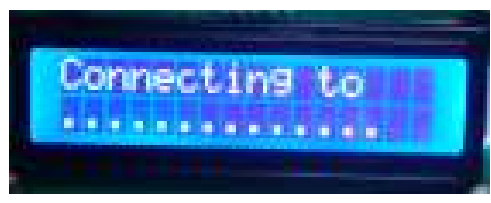

Figure 3.1. Network connectivity status

\section{b. Connected to MANDIRI SPBU Wifi}

In this system, the device can only communicate with only certain wifi address, namely MANDIRI SPBU so that the device will not be disturbed by other addresses as Figure 3.2 for the result

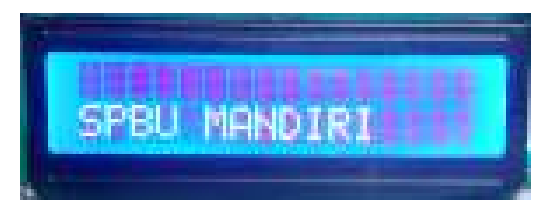

Figure 3.2 Connected Network

c. Get an IP address

After connecting to wifi, a certain address is needed which is used as an addressing between the device and the user / client and admin. In this case, the IP address is used as an 
BEST

Journal of Applied Electrical \& Science Technology - University of PGRI Adi Buana Surabaya

p-ISSN 2715-2871

e-ISSN 2714-5247

address for access to the smartphone or laptop application.

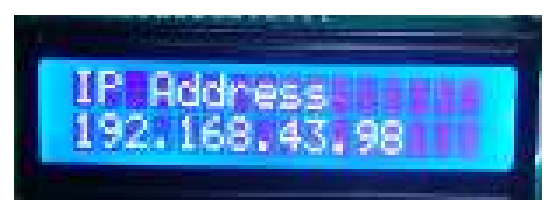

Figure 3.3 Getting IP Address

d. Testing Relays, Selenoid

This relay works as an ON / OFF switch for the solenoid valve coil. Relay condition will be active when it starts filling until the desired transaction value is reached. The solenoid valve that we use is the NC type, which is without a voltage, the valve will be closed.

Figure 3.1 Relay dan Solenoid valve Testing

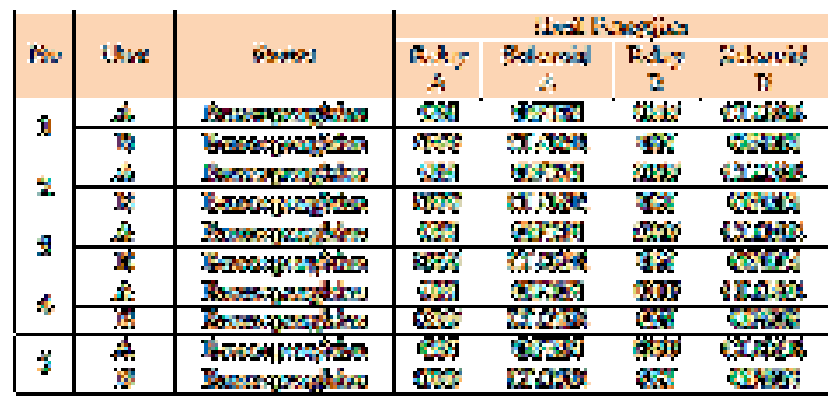

\section{Testing communication via Internet Web}

Testing the communication interface of the equipmentl with the internet web via a Smartphone or laptop. Web address used accordingly with the IP received by the Arduino ESP 8266 which has been shown as shown in Figure 4.3. If there is no internet service / data, the device cannot work.

The main menu on aplication as figure 3.4 wich needs user registered login.

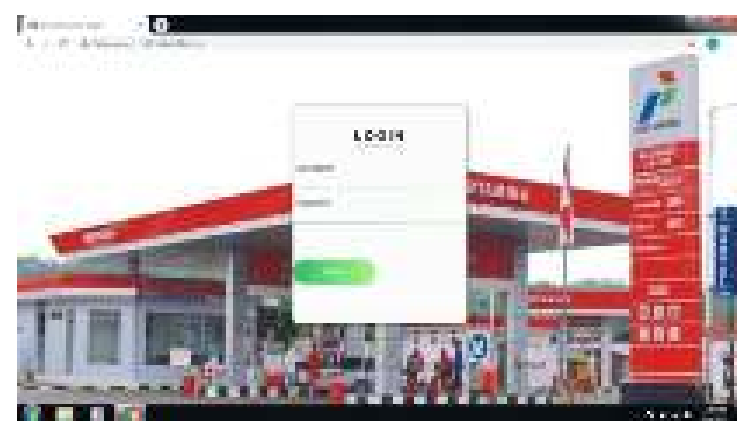

Figure 3.4 Login Page

The design of the IoT tool uses 2 user types,
1. Login as admin username: "admin" password: operator

\section{Login as client / user}

Client 1: Username "a" Password "a"

Client 2: Username "b" Password "b"

The difference in the menu that is displayed between admin \& client, namely

a. Admin: Displays the remaining balance data $(\mathrm{Rp})$ for all clients, Fill in the balance to the client and transfer or display all transaction history.

b. Client: Transaction history, remaining balance and fuel filling
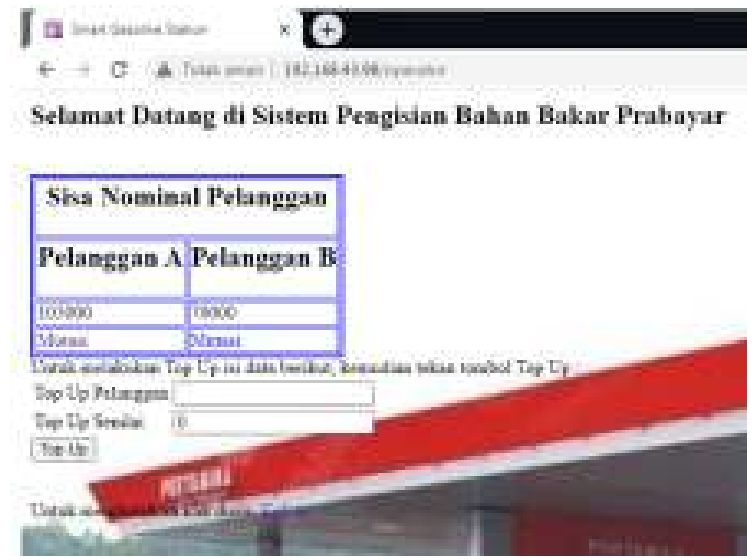

Figure 3.5 Admin Page

Admin, there is a menu of choices for Customers 1 or 2 who will top up the balance, the menu will appear in the admin menu as shown in Figure 3.5 above.

On the customer menu as shown in Figure 3.6 below, the web page displays the transaction history. To start fuel filling at a certain pump station, fill in the fields below the transaction for the pump selection and the desired transaction value

in

Rupiah

\section{A $192.168 .43 .98 / \mathrm{kamar}$}

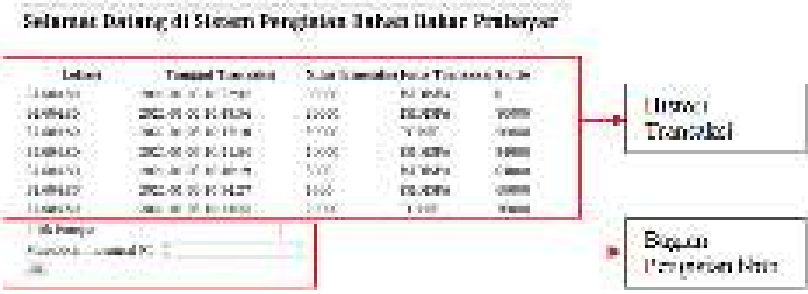


BEST

Journal of Applied Electrical \& Science Technology - University of PGRI Adi Buana Surabaya

Figure 3.6 Client Page

\section{Device Testing}

This test is to find out every input / output of a system is working.

Table 3.2 Testing of equipment

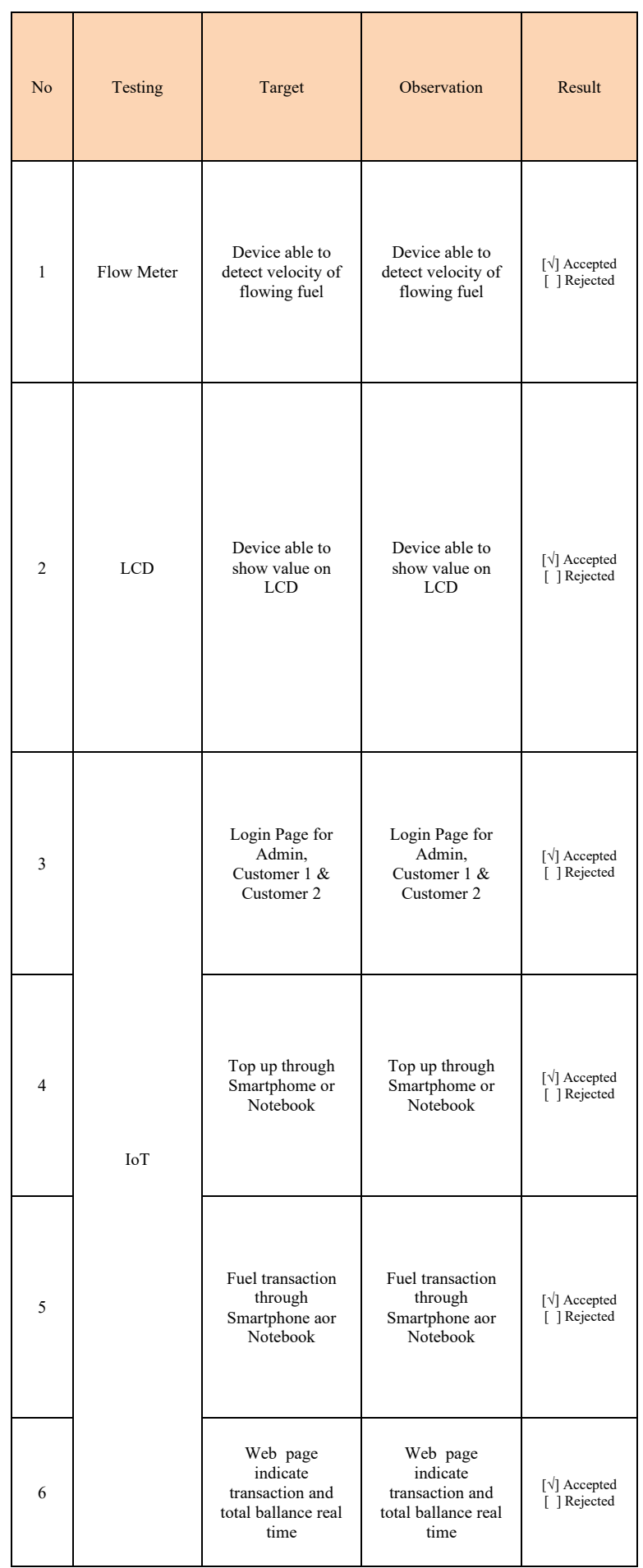

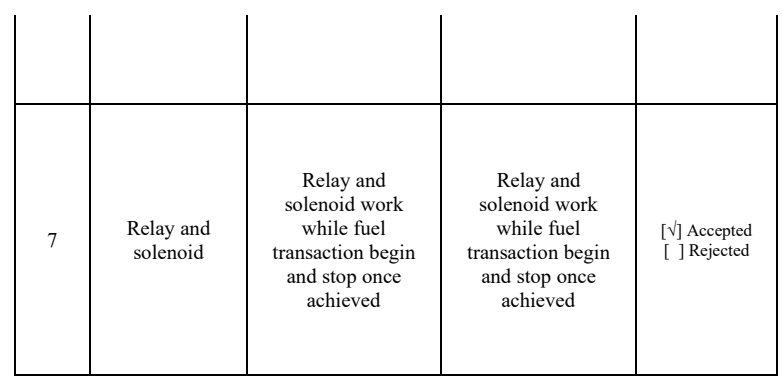

\section{Fuel Transaction Testing}

In system testing for fuel transactions, the results are in table 3.3. In this test, it is carried out on one of the client users and the pump station. In this case the transaction is carried out by entering the nominal value of Rupiah on the application.

Table 3.3 Fuel transaction testing and display compared to actual volume

\begin{tabular}{|cc|c|c|c|c|c|}
\hline Transaction & $\begin{array}{c}\text { Conversion } \\
\text { 6450/L } \\
\text { (Milititer) }\end{array}$ & $\begin{array}{c}\text { Velocity } \\
\text { (second) }\end{array}$ & $\begin{array}{c}\text { Actual } \\
\text { (Mililiter) } \\
\text { (Mililiter) }\end{array}$ & $\begin{array}{c}\text { Error } \\
\text { (Mililiter) }\end{array}$ & $\begin{array}{c}\text { Error ( } \\
\text { \%) }\end{array}$ \\
\hline $\mathrm{Rp}$ & 3,225 & 500 & 11.50 & 450 & 50 & $10.0 \%$ \\
\hline $\mathrm{Rp}$ & 6,450 & 1000 & 20.05 & 960 & 40 & $4.0 \%$ \\
\hline $\mathrm{Rp}$ & 9,675 & 1500 & 31.45 & 1550 & -50 & $-3.3 \%$ \\
\hline $\mathrm{Rp}$ & 12,900 & 2000 & 43.50 & 1800 & 200 & $10.0 \%$ \\
\hline $\mathrm{Rp}$ & 16,125 & 2500 & 55.10 & 2350 & 150 & $6.0 \%$ \\
\hline \multicolumn{7}{|c|}{ Error Average } \\
\hline
\end{tabular}

\section{Transaction History Testing}

In accordance with the design of this equipment, all transaction data, both top up balances and fuel transaction, are automatically stored in a data base that can be viewed through the application on a Smartphone or laptop.

Table 3.4 Transaction History

\begin{tabular}{|c|c|c|c|c|c|}
\hline No & Location & Transaction Date & Transaction value & Type & Balance \\
\hline 1 & 54.604 .80 & $2021-01-0115: 42: 26$ & 100,000 & Top Up & $1,150,000$ \\
\hline 2 & 54.604 .80 & $2021-01-0114: 50: 26$ & 1,000 & ISI DISP A & $1,050,000$ \\
\hline 3 & 54.604 .80 & $2021-01-0114: 32: 24$ & 1,000 & ISI DISP A & $1,060,000$ \\
\hline 4 & 54.604 .80 & $2021-01-0114: 08: 28$ & 1,000 & ISI DISP A & $1,070,000$ \\
\hline 5 & 54.604 .80 & $2021-01-0114: 05: 44$ & 1,000 & ISI DISP A & $1,080,000$ \\
\hline
\end{tabular}

\section{Top Up Balance Testing}

In this test, it is carried out on all client users via admin login. The balance top up test that has been carried out for each customer is as follows.

Table 3.3 Top up balance testing

\begin{tabular}{|l|l|l|l|}
\hline No & Top Up Balance & Balance value updated & Result \\
\cline { 2 - 3 }
\end{tabular}




\begin{tabular}{|c|c|c|c|c|c|c|c|c|c|}
\hline & \multicolumn{2}{|c|}{ User A } & \multicolumn{2}{|c|}{ User B } & \multicolumn{2}{|c|}{ User A } & \multicolumn{2}{|c|}{ User B } & \multirow[b]{2}{*}{ Pass } \\
\hline 1 & & 5,000 & & 10,000 & $\mathrm{Rp}$ & 5,000 & & 10,000 & \\
\hline 2 & $\mathrm{Rp}$ & 25,000 & $\mathrm{Rp}$ & 20,000 & $\mathrm{Rp}$ & 25,000 & $\mathrm{Rp}$ & 20,000 & Pass \\
\hline 3 & $\mathrm{Rp}$ & 50,000 & $\mathrm{Rp}$ & 30,000 & $\mathrm{Rp}$ & 50,000 & $\mathrm{Rp}$ & 30,000 & Pass \\
\hline 4 & $\mathrm{Rp}$ & 75,000 & $\mathrm{Rp}$ & 40,000 & $\mathrm{Rp}$ & 75,000 & $\mathrm{Rp}$ & 40,000 & Pass \\
\hline 5 & $\mathrm{Rp}$ & 100,000 & $\mathrm{Rp}$ & 50,000 & $\mathrm{Rp}$ & 100,000 & $\mathrm{Rp}$ & 50,000 & Pass \\
\hline
\end{tabular}

\subsection{Wiring Diagram Tools}

The wiring diagram for the equipment as follow assembled component.

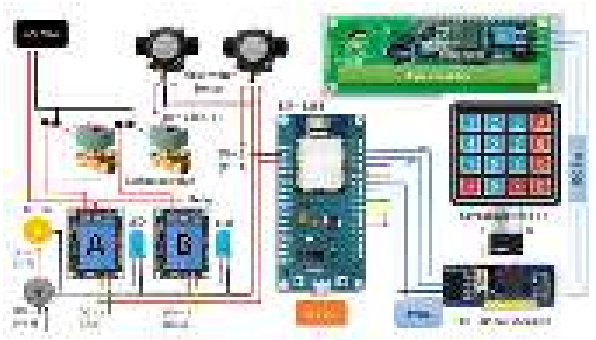

Figure 3.8 Hardware Scematic

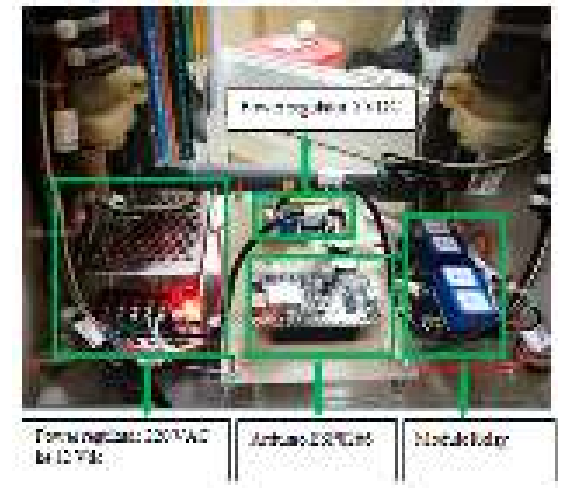

Figure 3.9 Hardware Layout

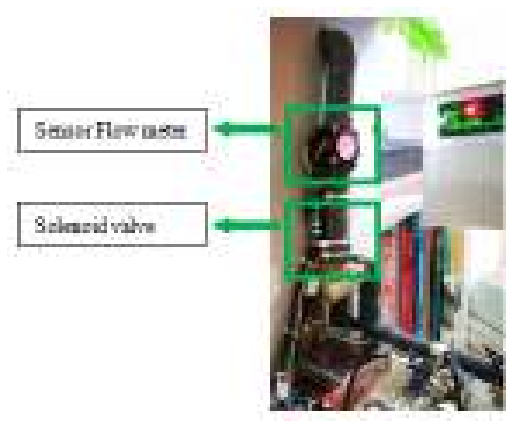

Figure 3. Flow meter and solenoid valve layout

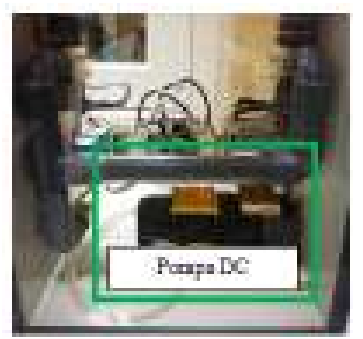

Figure 11. DC Pump

\subsection{Discussion}

Based on the testing that have been carried out, the system that has been designed is working properly, even though there are errors in some circuits or sensors that are relatively small.

A management system for monitoring fuel consumption displayed in a data base that can be accessed via an application on a smartphone and the web. The device works well. The system can display all transaction, both top up balances and refueling gasoline either via smartphone or laptop in detail for the location, date, time, top up and total balance.

Fuel transactions using the Yf-S201 flow sensor which can be seen on the LCD / display are controlled using the Arduino. In this case the system works well, the display can show the desired rupiah and the number of milli liters issued with an error of $5.3 \%$.

Control system for fuel pump station with smartphones / laptops and balance top up. In this section the system works well, when the transaction process (via a smartphone or laptop) starts, the equipment works by opening the solenoid valve automatically at the selected pump station and the fluid comes out through hose and the flow will stop when the value has been reached. In the case of initializing balances, the system also works properly. The transaction data is stored in detail for the location, date, time, top up and total balance.

\section{CONCLUSIONS}

Based on the results of the research and discussion that has been described in the previous chapters, it can be concluded as follows:

The designed tool is equipped with the following facilities:

1. Management data for the history of all transactions can be accessed via a Smartphone or laptop which is recorded in detail for the location of filling, date, time and top up value and total balance.

2. Control when charging fuel can be done automatically by using a Smartphone or laptop, only through the local wifi network 
with the desired value during the transaction with an error value of $5.3 \%$, and the flow being issued is displayed on the Display / LCD.

3. Topping up the balance can be done only using the user / Admin either via Smartphone or laptop.

\section{REFERENCES}

[1] David Eka Setiabudi . (2019). Pertumbuhan dinamis konsumsi BBM

[2] Bensinkita. (2020). Jenis BBM Pertamina yang Berkualitas dan Ramah Lingkungan

[3] Saiful Anwar. (2015). Perancangan Sistem Pengisian Bahan Bakar Premium dan Solar Bersubsidi dengan Teknologi RFID Sebagai Pembatas Jumlah Beli dan Pembeli. Jurusan Teknik Elektro, Teknik Elektro Universitas Dipenogero, Semarang

[4] Risna, Harrizki Arie Perdana. (2014). Rancang Bangun Aplikasi Monitoring Penggunaan Air PDAM Berbasis Mikrokontroler Arduino Uno. Teknik informatika STMIK Atma Luhur, Kepulauan Bangka Belitung

[5] Elektrologi, Rekayasa Perangkat Elektronika. (2014). Water Flow Sensor Yf s-201

[6] Winda Gissella Ginting. (2017). Rancang Bangun Alat Ukur Debit Air Berbasis Mikrokontroler Arduino Uno Dengan Menggunakan Sensor Yf-201.

[7] Leo Louis. (2018). Working Principle of Arduino and Using it as a Tool for Study and Research

[8] Zozo Hassan and Hesham Arafat. (2015). Internet of Things (IoT): Definitions, Challenges, and Recent Research Directions

[9] Bank Indonesia. (2006). Upaya Meningkatkan Penggunaan Alat Pembayaran Non Tunai Melalui Pengembangan E-Money.

[10] Rachmadi Usman, (2017). Karakteristik Uang Elektronik Dalam Sistem Pembayaran

[11] Sujiwa, Akbar, and Sagita Rochman. "Pengembangan Sistem Kontrol Serta Monitoring Suhu dan Volume Air Berbasis
Web Pada Perangkat Desalinasi Air Laut." SNHRP (2019): 1-9.

[12] Rochman, Sagita, and Bagus Ilham Yunianto. "PROTOTYPE AUTOMATIC LIGHTS CONTROL SYSTEM IN THE MOSQUE AREA BASED ON ARDUINO NANO." BEST: Journal of Applied Electrical, Science, \& Technology 1.1 (2019): 32-35.

[13] Rochman, Sagita, and M. Nushron Ali Mukhtar. "CLASSIFICATION OF THE QUALITY OF HONEY USING THE SPECTROFOTOMETER AND MACHINE LEARNING SYSTEM BASED ON SINGLE BOARD COMPUTER." Tibuana 2.01 (2019): 45-49. 